Bull. Fac. Agric., Cairo Univ., 71: 297-306(2020).

\title{
PRODUCTION OF MARSHMALLOW SWEETS FREE OF GOLDEN SYRUP USING SOME FRUITS AND VEGETABLES JUICES.
}

(Received: 8.12. 2020)

\author{
By \\ Nesreen M. E. Ali. \\ Food Technology Research Institute, Agricultural Research Center, Giza, Egypt.
}

\begin{abstract}
Marshmallow is a special product of chewing soufflé, processed on the basis of sugar and gelatin. It belongs to popular confectionery products. Marshmallow is one of the earliest confections known to humanity. Currently, the world is moving towards maximizing their natural sources, which are used in food processing, with avoiding addition of artificial colors or flavors. Sugar, glucose syrup and gelatin are the main components of marshmallow sweets. Gelatin is useful for joints and articular ligaments of bones. It is clear that, sugar and glucose syrup are one of the main factors for obesity, diabetes and most of other diseases. This research, tended to solve this problem by producing marshmallow (candy) without glucose syrup and reducing the amount of sugar. Resorted juices of some fruits and vegetables, such as strawberry, persimmon, wholly prickly pear, carrots and pumpkin were used as alternative colors and flavor compared to the commercial marshmallow (control) and the blank sample (with glucose syrup), as a novel marshmallow candy product. The obtained results indicated that, wholly prickly pear marshmallow sample had superior value of antioxidative activity $(60.41 \%)$. Wholly prickly pear sample was the lowest $(39.27 \%)$ total sugar. Wholly prickly pear, carrot and pumpkin were characterized by most of the mineral contents, except Selenium mineral content which was $(0.0 \mathrm{ppm})$. The water activity $\left(\mathrm{a}_{\mathrm{w}}\right)$ in general, indicated that, there are no significant differences at $\mathrm{p} \leq 0.05$., before or after storage period. Reconstitution ratio values after $6 \mathrm{hrs}$., for some samples were the best compared to (control and blank). The consumers preferred the classical marshmallow with golden syrup (blank), strawberries, and pumpkin as well. Wholly prickly pear enriched marshmallow compared to control sample. Therefore, we recommend to make marshmallows from natural sources and free of glucose syrup with a little sugar, to reduce the processing cost and keep the children health as well as the adults. It can provide a final product with natural and healthy ingredients.
\end{abstract}

Key words: Marshmallow (soft candy), free syrup, natural color/flavor, juices, Strawberries (Fragaria $\times$ ananassa), Persimmon (Diospyros kaki-'fuyu'), Carrots (Daucus carota subsp. Sativus), Pumpkin (Cucurbita pepo), Wholly Prickly Pear (Opuntia ficus-indica).

\section{INTRODUCTION}

Marshmallow is an aerated confectionery product with a characteristic foamy structure created when air and moisture is incorporated into a sugar mixture containing gelatin. The air entrapped in the marshmallow matrix is responsible for its fluffy texture. Moisture absorption/loss of marshmallows during storage and transportation is one of the most important quality defects that make the product unpalatability: (Kirtil et al., 2015). Marshmallows are simply described as air bubbles surrounded by sugar syrup. The sugar syrup, made of sucrose, corn syrup, and water, is cooked at appropriate temperature to reach the desired water content, which allows air to be whipped into the matrix by mechanical agitation. Source of proteins is such as gelatin, and Arabic gum. During whipping, the density of the product decreases as the syrup and foam mixture expands into a light, fluffy marshmallow. Marshmallows may be either non-grained or grained crystal aggregates, depending on the ratio of sucrose to corn syrup, (Sucharzewska et al., 2003; Ergun et al., 2010).The results of investigating on the influence on humans organism of combinations of food supplements in quantities typical for distributed food products for children, show that chemical dyes decrease growth of nerve cells in 4-7 times (Kolmakova, 2008). Gelatin is an essential ingredient in the manufacture of marshmallow, because of its 
ability to produce and support the foam formed and forms a film that captures air bubbles, (Kirtil, et al.,2017). The type gelatin used for products such as marshmallow confectionary is gelatin with medium to low viscosity (Demirhan,et al., 2012). Technology is about the basis for sample preparation for typical marshmallow formulation includes the stages of the swelling and dissolution of gelatin and egg albumin and dissolution followed by boiling sugar, glucose syrup and water, adding inverted sugar to the boiled syrup and shaking the mixture (Minifie,1989). The genus of Prickly Pear (Opuntia ficus-indica) is characterized by the production of a hydrocolloid, commonly known as mucilage, which forms molecular networks that are able to retain large amounts of water, resulting in colloidal and very viscous suspensions or jellied masses (Sepulveda et al., 2007). Two distinctive, water-soluble, highmolecular-weight, pectic polysaccharide materials occur in Opuntia cladodes and fruits, namely mucilage and a calcium-sensitive gelling fraction. Mucilage do not gel in the presence of calcium (Goycoolea and Cardenas, 2003). The experimental data indicated that the liquid preparations under study have a surface tension sufficient to provide stable foaming in the final product, which is not inferior to the classical marshmallow formulation from this point of view. Based on the study, the organoleptically acceptable and economically viable marshmallow samples were selected, each of which successfully reproduces the main attributes of the well-proven and widely consumed traditional marshmallow, (Nepovinnykha et al., 2018). In this case, the combination of invert sugar and sucrose has a synergistic effect and provides a decrease in water activity by about $85 \%$. The reverse ratio of the above components at the same concentration makes it possible to reduce the water activity by about $35 \%$. The application of various volumes of polysaccharides does not practically affect a change in the water activity in the system, (Zharinov, et al., 2009). Besides their nutraceutical properties, polyphenols are indicative of the quality of fruits and vegetables. The effectiveness of the antioxidant action of these bioactive compounds depends on their chemical structure and concentration in foods, (Pietta,2000).

The study aims to develop a marshmallow technology through processing marshmallows to produce products free of golden syrup (glucose syrup), therefor to reduce sugar and to be suffice with used sugar and natural components such as (fruits/vegetables) juices in order to make the marshmallow as products healthier compared to both of control (commercial) and blank classic (with golden syrup- vanilla) marshmallow samples.

\section{MATERIAL AND METHODS}

\subsection{Materials}

All of the raw materials used in these experiments were purchased from market near Giza as fresh for both of vegetable and fruit in (winter/summer) season (2019) which included; Strawberries (Fragaria $\times$ ananassa), Persimmon (Diospyros kaki-'fuyu'), Carrots (Daucus carota subsp. Sativus), Pumpkin (Cucurbita pepo), and Wholly Prickly Pear (Opuntia ficus-indica), all were used in juice form. Blank sample (with syrup) was done. Artificial marshmallow was purchased from the local supermarkets in Giza, (Egypt).

\subsection{Methods}

2.2.1. Preparation of each natural extracts strawberries, persimmon, carrots, and pumpkin as well wholly prickly pear (after removing the thorns), were washed well with tap water. Strawberries, and persimmon, were squeezed in a blender, but carrots, and pumpkin in carrot juicer. Each of extracts was filtered, then used in juice form. Knowing that, blank sample (with golden syrup) was prepared, and used artificial marshmallow (control) which both of them were for comparison.

\subsubsection{Preparation of Natural marshmallows} The producing recipe contains the following ingredients: strawberries, persimmon, carrots, pumpkin, and wholly prickly pear juices (200 $\mathrm{ml}$ ), free of golden syrup, coarse sugar (360 g), gelatin (15 g), vanilla, confectioners (powdered) sugar, and corn starch (corn flour). Blank sample (with syrup) was prepared in the same manner.

\subsection{Main Physical Parameters and Chemical Composition of marshmallows (soft candies)}

The determination method of moisture content, total soluble solids, crude fiber, ash, minerals, total sugars, reducing sugars and nonreducing sugars content were performed according the method described in AOAC, (2019).

\subsection{Non-enzymatic browning test (Color index at $420 \mathrm{~nm}$.) \\ The increases absorbence of a sample} extract at $440 \mathrm{~nm}$ was taken as a measure of 
non-enzymatic browning. The color also was measured at $420 \mathrm{~nm}$. Extract of sample was (4-5) gram with $100 \mathrm{ml}$ of $60 \%$ alcohol for $12 \mathrm{hr}$. and filter. For samples containing chlorophyll, alcoholic extract was shake with three lots of 50 $\mathrm{ml}$ benzene. If the filtrate not clear, it was refiltered using filter aid. The colour was measured at $440 \mathrm{~nm}$ using $60 \%$ aqueous alcohol as blank, according to Ranganna (1977).

\subsection{Antioxidants Activity of 2,2-Diphenyl-1- picrylhydrazyl (DPPH)\%}

The free radical scavenging effect of plant extracts was assessed by the discoloration ethanol solution of 2,2Diphenyl-1-picrylhydrazyl (DPPH) radical 0.2 aromatic in ethanol according to (Aromatic et al., 2013).

\subsection{Physical Properties}

Texture Attributes such as texture profile parameters (Hardness, Cohesiveness, Springiness, Gumminess and Chewiness) were measured.

Texture profile analysis test of samples whose shape was $3 \times 3 \times 3$ clyndrical was done using a Universal Testing Machine (TMS-Pro) Food Technology Corporation, Sterling, Verginia, USA) equipped with $1000 \mathrm{~N}$ (250 lbf) load cell and connected to a computer programmed with Texture ProTM texture analysis software (program, DEV TPA with holding time between two seconds cycle). A flat rod probe $(49.95 \mathrm{~mm}$ in diameter) was used to uniaxially compress the samples with the following parameters conduction to $25 \%$ of their original height. Each sample was subjected to two subsequent cycles (bites) of compressiondecompression.

Data were saved in computer and the texture profile parameters were calculated from DEV TPA texture analyzer and computer interface. Calculation described by Szczesniak et al., (1963) and Bourne (1978) was used to obtain the following texture profile parameters (Hardness, Cohesiveness, Springiness, Gumminess and Chewiness).

\subsection{Water activity $\left(a_{w}\right)$}

The major advantages of the chilled mirror dew point method are its speed and accuracy. Chilled mirror dew point is a primary approach to measurement of relative humidity based on fundamental thermodynamic principles. Chilled mirror instruments make accurate $\left( \pm 0.003 \mathrm{a}_{\mathrm{w}}\right)$ measurements in less than 5 minutes. Since the measurement is based on temperature determination, calibration is unnecessary, but running a standard salt solution checks proper functioning of the instrument. If there is a problem, the mirror is easily accessible and can be cleaned in a few minutes. For some applications, fast readings allow manufacturers to perform at-line monitoring of a product's water activity (Rockland and Nishi,1980).

\subsection{Reconstitution of marshmallows (soft candies)}

Reconstitution of marshmallow (soft candies) was determined according to the method stated by Von Loesecke (1955) as following is: 10 grams the tested dry material samples were placed in $600 \mathrm{ml}$ Pyrex beaker, 80 to $150 \mathrm{ml}$ distillated water were added, covered with a watch glass, placed on electric heater, as boiled for $5 \mathrm{~min}$., removed from the heater and dumped into a 75 min., Buchner funnel which was covered with a coarsely porous filter paper. Suction was gently applied and drained with careful stirring for one min., or until the drip from the funnel has almost stopped. Samples were removed from the funnel and a weighted calculation was made to express in terms of "Reconstitution ration".

Reconstitution ratio $(\%)=$

The drained weight of the rehydration sample (WR). X100

The origin weight of the dehydration sample (WD).

\subsection{Sensory evaluations of Marshmallows product}

For the sensory evaluated a simple hedonic scale with a small number of points (from 1 to 10 with $1-i$ don't like it and 10 - i like it very much) was used in order to evaluate the first impression. The aspect, the quality attributes (color, taste, flavor, texture, appearance and overall palatability of the samples of soft candies compared to artificial marshmallows (control) were tested. Using suggested scale was evaluated for their sensory characteristics by ten volunteers from the staff of the Processing Crops, Research Dep., Agric. Res. Center, Giza, Egypt. Palatability is giving numerical scores to each of their attributes from 10 volunteers. The produced was organoleptically judged by groups of (10) panel volunteers. The quality was scored on a scale (1 to 10). The following scale was applied to all samples for color, taste, flavor, Texture, Appearance, and overall palatability as follows:

Excellent $=(10)$, Very good $=(8-9)$, Palatable $=$ (6-7), and Unpalatable $=(0-5)$. These proportion were scored on a scale from 1-10 according to Watts et al., (1989). 


\subsection{Statistical analysis}

The obtained data were statistically analyzed by analysis of variance method using General Liner Model (GLM) procedure according to Sendecor and Cochran (1997). Means were obtained using Duncan's test at a degree of significance $(\mathrm{P} \leq 0.05)$. Statistical analyses were made using the procedure of the SAS software system program (SAS, 1997).

\section{RESULTS AND DISCUSSION}

Marshmallow is sugar-candy with foam-like structure. A simple sugar-free marshmallows recipe contains with just 3 ingredients. These low carb- keto - marshmallows have the same flavor and preferred texture, without sugar or corn syrup. Just a few ingredients are needed to make these sweets, but surprisingly sugar-free marshmallows. This low carb keto marshmallows recipe is made without corn syrup or sugar (of course), but the end result has the same taste and texture would from the storebought sugary kind be gotten (Periche et al.,2016).Technology of the basis for sample preparation of typical marshmallow formulation includes the stages of the swelling and dissolution of gelatin and egg albumin and dissolution followed by boiling sugar, glucose syrup and water, adding inverted sugar to the boiled syrup and shaking the mixture, (Minifie,1989).From data presented in Table (1), it could be observed that, Moisture content was from $(83.95 \%$ to $79.48 \%)$ and thus total solids represent the opposite were from $(16.05 \%$ to $96.91 \%$ ). These total solids are divided into two parts; total soluble solids which were from (37.65\% to $66.20 \%$ ) compared to the control and blank were (49.20\% and $64.67 \%)$ respectively. These including total sugars were from (39.27\% to $56.81 \%$ ) compared to the control and blank (57.04 \% and $47.69 \%$, respectively). Reducing sugars were from (5.13 $\%$ to $44.70 \%$ ) compared to control and blank were $(36.99 \%$ and $10.28 \%$, respectively). Also non-reducing sugars were from $(1.48 \%$ to $39.56 \%$ ), compared to the control and blank were $(20.05 \%$ and $37.51 \%$, respectively). Insoluble solids which include the fibers were $(0.8 \%$ to $2.4 \%)$ compared to control and blank were $(1.8 \%$ and $2.8 \%$, respectively), while ash content was from ( $0.11 \%$ to $0.46 \%$ ) compared to the control and the blank were $0.16 \%$ and $0.14 \%$, respectively). Finally, it was clear from these data that, the processed marshmallow product has nutritional value and it could be considered as a good source of fiber, ( Periche $e t$ al., 2015).

The antioxidants activities were determined by 2,2-Diphenyl-1-picrylhydrazyl (DPPH)\%. The values were from $(57.28 \%$ to $60.41 \%)$. From the results in Table (2), those values compared to the control and the blank samples were $(54.15 \%$ and $54.30 \%$, respectively). It could be indicated that, the antioxidants content of the produce marshmallow products had a high, gives relative feature to the produced, these products marshmallow as well the added value. It is well established that fruits and vegetables contain antioxidative vitamins and various phytochemicals with antioxidative activity, (Miean, and Mohamed, 2001; Hill, 1997). Color index at $(420 \mathrm{~nm}$. ,), it was observed to have no significant differences at $\mathrm{p} \leq 0.05$., among samples (carrot, pumpkin and wholly prickly pear) including the blank sample, except strawberries, and persimmon marshmallow samples including the control which there are significant differences at $\mathrm{p} \leq 0.05$.

Table (1): Gross Chemical Composition of Marshmallows Free of Syrup Products.

\begin{tabular}{|c|c|c|c|c|c|c|c|c|c|}
\hline Treatments. & $\begin{array}{l}\text { Moisture } \\
\text { Content } \\
(\%)\end{array}$ & $\begin{array}{c}\text { Total } \\
\text { Solids } \\
\text { TS) } \\
(\%)\end{array}$ & $\begin{array}{c}\text { Total } \\
\text { Soluble } \\
\text { Solids } \\
\text { (TSS) } \\
\text { ('Brix) }\end{array}$ & $\begin{array}{l}\text { Fibers } \\
(\mathrm{g} / \mathbf{1 0 0} \\
\mathrm{g})\end{array}$ & $\begin{array}{l}\text { Protein } \\
\text { (\%) }\end{array}$ & $\begin{array}{l}\text { Ash } \\
\text { (\%) }\end{array}$ & $\begin{array}{c}\text { Total } \\
\text { Sugars } \\
(\%)\end{array}$ & $\begin{array}{l}\text { Reducing } \\
\text { Sugars } \\
(\%)\end{array}$ & $\begin{array}{c}\text { Non- } \\
\text { reducing } \\
\text { Sugars } \\
(\%)\end{array}$ \\
\hline$* *$ Control Commercial). & $83.95^{\mathrm{a}}$ & $16.05^{b}$ & $49.20^{\mathrm{bc}}$ & $1.8^{b}$ & ND & $0.16^{b}$ & $\mathbf{5 7 . 0 4 ^ { \mathrm { a } }}$ & $36.99^{b}$ & $20.05^{b}$ \\
\hline $\begin{array}{l}\text { Blank (with golden } \\
\text { syrup). }\end{array}$ & $73.91^{b}$ & $26.09^{a}$ & $64.67^{\mathrm{a}}$ & $2.8^{\mathrm{a}}$ & ND & $0.14^{b}$ & $47.79^{b}$ & $10.28^{d}$ & $37.51^{\mathrm{a}}$ \\
\hline Strawberries & $76.85^{\mathrm{ab}}$ & $23.15^{\mathrm{a}}$ & $49.57^{b c}$ & $0.8^{\mathrm{c}}$ & ND & $0.12^{\mathrm{b}}$ & $44.08^{b}$ & $24.60^{c}$ & $19.48^{\mathrm{c}}$ \\
\hline Persimmon. & $79.48^{\mathrm{ab}}$ & $20.52^{\mathrm{ab}}$ & $37.65^{c}$ & $1.5^{\mathrm{b}}$ & ND & $0.10^{b}$ & $44.93^{b}$ & $43.45^{\mathrm{a}}$ & $1.48^{\mathrm{e}}$ \\
\hline Carrots. & $74.95^{b}$ & $25.05^{\mathrm{a}}$ & $60.97^{a b}$ & $2.4^{\mathrm{a}}$ & ND & $0.46^{\mathrm{a}}$ & $46.62^{b}$ & $7.03^{\mathrm{e}}$ & $39.56^{\mathrm{a}}$ \\
\hline Pumpkin. & $73.09^{b}$ & $26.91^{\mathrm{a}}$ & $66.20^{\mathrm{a}}$ & $1.3^{\mathrm{b}}$ & ND & $0.11^{\mathrm{b}}$ & $56.81^{a}$ & $44.70^{\mathrm{a}}$ & $12.11^{\mathrm{d}}$ \\
\hline Wholly Prickly Pear. & $74 . .82^{b}$ & $25.18^{\mathrm{a}}$ & $\mathbf{5 2 . 0 8}^{\mathrm{b}}$ & $0.8^{\mathrm{c}}$ & ND & $0.15^{\mathrm{b}}$ & $39.27^{\mathrm{c}}$ & $5.13^{f}$ & $34.14^{\mathrm{a}}$ \\
\hline
\end{tabular}

* Means followed by different letters in the same column are significant differences at $p \leq 0.05$.

**Control: Imported marshmallow (Commercial). 
Table (2): Total Antioxidants Activity (DPPH \%) /Colors Index at $(420 \mathrm{~nm})$ of Marshmallows Free of Syrup products.

\begin{tabular}{|l|c|c|}
\hline \multicolumn{1}{|c|}{ Parameters. } & $\begin{array}{c}\text { Antioxidative } \\
\text { Activity. } \\
\text { (DPPH \%) }\end{array}$ & $\begin{array}{c}\text { Color } \\
\text { Index } \\
\text { at } \mathbf{( 4 2 0 ~} \mathbf{~ n m})\end{array}$ \\
\hline Control (Commercial). & $\mathbf{5 4 . 1 5}^{\mathbf{c}}$ & $\mathbf{0 . 0 8 2 3}^{\mathbf{c}}$ \\
\hline Blank (with golden syrup). & $\mathbf{5 4 . 3 0}^{\mathbf{c}}$ & $\mathbf{0 . 0 2 0 7}^{\mathbf{d}}$ \\
\hline Strawberries & $\mathbf{5 7 . 2 9}^{\mathbf{b}}$ & $\mathbf{0 . 1 4 4 3}^{\mathbf{b}}$ \\
\hline Persimmon. & $\mathbf{5 7 . 6 0}^{\mathbf{b}}$ & $\mathbf{0 . 2 4 3 8}^{\mathbf{a}}$ \\
\hline Carrots. & $\mathbf{5 7 . 4 5}^{\mathbf{b}}$ & $\mathbf{0 . 0 2 8 2}^{\mathbf{d}}$ \\
\hline Pumpkin. & $\mathbf{5 7 . 2 7}^{\mathbf{b}}$ & $\mathbf{0 . 0 3 5 4}^{\mathbf{d}}$ \\
\hline Wholly Prickly Pear. & $\mathbf{6 0 . 4 1}^{\mathbf{a}}$ & $\mathbf{0 . 0 3 1 7}^{\mathbf{d}}$ \\
\hline
\end{tabular}

*Means followed by different letters in the same column are significant differences by Duncan's multiple tests $(p \leq$ 0.05).

The results in Table (3), indicated that, all types of marshmallow were contained moderate amounts of minerals such as $(\mathrm{Fe}, \mathrm{Ze}, \mathrm{Ca}, \mathrm{Mg}$, and $\mathrm{Se}$ ).The results were showed also that, some types contained from 4 to 5 times the amount of iron compared to the control and blanks, and as that of zinc element, while the calcium element was 6 times the amount compared to the control and the blank samples. It could be observed also that, there is a disappearance the selenium element among the samples including blank compared to the control that there is no explanation for it. This could indicate, the processed marshmallow product can be used for children with anemia (iron), cretinism (zinc) and bone problems (calcium and magnesium), DailyIntake, FDA (2020).

Physical properties - texture attributes such as (Hardness, Cohesiveness, Springiness, Gumminess, Chewiness, and Adhesiveness). Knowing that, samples were stored for (3 months) at ambient temperature $\left( \pm 25^{\circ} \mathrm{C}\right)$, and rheological measurements were made on them before/ after storage. There are Young's modulus: "the polymer networks with a higher concentration of knots are characterized by a higher resistance to compression under elastic deformation. At the same time, the elasticity of the material established as a result of the experiment gave a notion of the distance between the knots of the polymer network, which is approximately the same in all the analyzed samples" ( Nepovinnykha, et al.,2018), that shows the attributes of marshmallow product which it is possesses.

As could be seen from Table (4), hardness attribute; before storage case for carrot marshmallow sample was the best followed by wholly prickly pear and persimmon compared to control(commercial) sample, as well pumpkin compared to blank (with golden syrup) had the same values but the lowest one was strawberries marshmallow sample, while after storage case, it is clear that, the control had the highest value and increasing in its hardness attribute followed by persimmon, carrot, and strawberries, and also increasing, but pumpkin and wholly prickly pear were occurred decreasing in their values and sharp low in values for wholly prickly pear marshmallow. Cohesiveness; before storage, there is no significantly different at $(\mathrm{p}<0.05)$, between all samples including blank sample, while strawberries which had represented the highest value was the best but, the control was the lowest one. On the other hand, in storage case, persimmon, pumpkin, wholly prickly pear including blank sample and control were increased but strawberries and carrot were decreased their values, furthermore strawberries had a sharp decrease. Persimmon and pumpkin had represented the highest and were the best. Springiness; before storage period, the most of samples compared to both of control and blank

Table (3): Main Minerals in Marshmallows Free of Syrup Products On (dry weight basis).

\begin{tabular}{|c|c|c|c|c|c|c|c|c|c|c|}
\hline $\begin{array}{l}{ }_{\text {Items. }} \\
\text { Main Minerals } \\
\text { (mg/kg). }\end{array}$ & $\mathbf{F e}$ & $\begin{array}{c}\text { \%RD } \\
\text { I }\end{array}$ & $\mathbf{Z n}$ & \%RDI & $\mathrm{Ca}$ & \%RDI & Mg & \%RDI & Se & \%RDI \\
\hline *RDI. & 18 & & 11 & & 1.300 & & 420 & & 55 & \\
\hline $\begin{array}{l}* * \text { Control. } \\
\text { (Commercial). }\end{array}$ & $5.35^{\mathrm{e}}$ & 29.72 & $7.67^{\mathrm{c}}$ & 69.73 & $253.10^{c}$ & 19.24 & $67.53^{d}$ & 16.08 & $7.10^{\mathrm{a}}$ & 12.91 \\
\hline $\begin{array}{l}\text { Blank (with golden } \\
\text { syrup). }\end{array}$ & $7.82^{d}$ & 43.44 & $2.2^{\mathrm{b}}$ & 20.00 & $387.07^{\mathrm{c}}$ & 29.77 & $92.24^{\mathrm{d}}$ & 21.96 & $0.00^{b}$ & 0.0 \\
\hline Strawberries. & $8.65^{d}$ & 48.06 & $16.08^{b c}$ & 146.18 & $279.92^{c}$ & 21.53 & $107.70^{c}$ & 25.64 & $0.00^{b}$ & 0.0 \\
\hline Persimmon. & $7.12^{d}$ & 39.56 & $14.51^{\mathrm{bc}}$ & 131.91 & $285.91^{c}$ & 21.99 & $88.62^{d}$ & 21.10 & $0.00^{\mathrm{b}}$ & 0.0 \\
\hline Carrots. & $20.40^{b}$ & 113.33 & $19.18^{b}$ & 174.36 & $502.10^{b}$ & 38.62 & $136.07^{\mathrm{c}}$ & 32.40 & $0.00^{b}$ & 0.0 \\
\hline Pumpkin. & $15.58^{c}$ & 86.56 & $19.76^{b}$ & 179.64 & $623.78^{b}$ & 47.98 & $317.00^{b}$ & 75.48 & $0.00^{b}$ & 0.0 \\
\hline Wholly Prickly Pear. & $30.19^{a}$ & 167.72 & $33.22^{\mathrm{a}}$ & 274.73 & $1416.10^{\mathrm{a}}$ & 108.93 & $549.11^{\text {a }}$ & 130.74 & $0.00^{b}$ & 0.0 \\
\hline
\end{tabular}

Means followed by different letters in the same column are significant differences by Duncan's multiple tests $(p \leq 0.05)$.

* Reference-Daily-Intake (RDI) (mg/kg) for Adults / Children $\geq 4$ Years, ( www.fda.gov/nutritioneducation). 
Table (4): Textural Attributes such as Texture Profile Parameters / Water Activity for Marshmallows Free of Syrup Products before / after (3 Mons., ) at Ambient Temp., $\left( \pm 25^{\circ} \mathrm{C}\right)$ Storage.

\begin{tabular}{|c|c|c|c|c|c|c|c|c|c|c|c|c|c|c|}
\hline \multirow[t]{4}{*}{ Parameters. } & \multicolumn{12}{|c|}{ Physical property } & \multirow{2}{*}{\multicolumn{2}{|c|}{$\begin{array}{c}\text { Water activity } \\
\left(\mathbf{a}_{\mathbf{w}}\right) .\end{array}$}} \\
\hline & \multirow{2}{*}{ 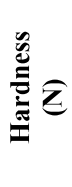 } & \multirow{2}{*}{ 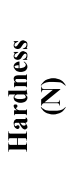 } & \multirow{2}{*}{ 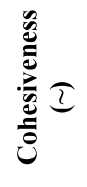 } & \multirow{2}{*}{ 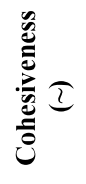 } & \multirow{2}{*}{ 总 } & \multirow{2}{*}{ 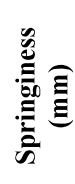 } & \multirow{2}{*}{ 总 } & \multirow{2}{*}{ 兽乞 } & \multirow{2}{*}{ 总 } & \multirow{2}{*}{ 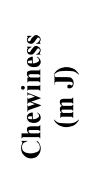 } & \multirow{2}{*}{ 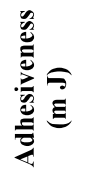 } & \multirow{2}{*}{ 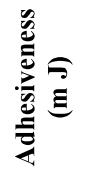 } & & \\
\hline & & & & & & & & & & & & & Before & After \\
\hline & 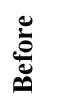 & $\sum_{\bar{Z}}^{\bar{\Xi}}$ & قِّ & ऐè & 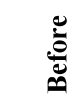 & 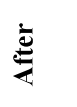 & 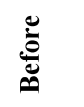 & 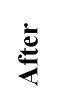 & $\frac{\mathscr{U}}{\tilde{U}}$ & ऐè & 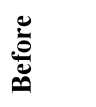 & $\sum^{\grave{2}}$ & & \\
\hline$* *$ Control (Commercial). & $1.3^{\mathrm{a}}$ & $4.06^{\mathrm{a}}$ & $0.88^{b}$ & $0.89^{b}$ & $3.97^{\mathrm{a}}$ & $6.29^{b}$ & $1.20^{\mathrm{a}}$ & $3.41^{\mathrm{a}}$ & $4.65^{\mathrm{ab}}$ & $21.5^{\mathrm{a}}$ & $0.294^{b}$ & $0.20^{\mathrm{b}}$ & $0.626^{b}$ & $0.472^{\mathrm{c}}$ \\
\hline $\begin{array}{l}\text { Blank (with golden } \\
\text { syrup). }\end{array}$ & $1.0^{\mathrm{ab}}$ & $1.20^{\mathrm{c}}$ & $0.90^{b}$ & $0.99^{\mathrm{ab}}$ & $3.99^{\mathrm{a}}$ & $6.90^{b}$ & $0.90^{b}$ & $1.18^{\mathrm{c}}$ & $3.72^{b}$ & $8.20^{b}$ & $0.320^{\mathrm{ab}}$ & $0.00^{\mathrm{c}}$ & $0.792^{\mathrm{a}}$ & $0.771^{\mathrm{a}}$ \\
\hline Strawberries & $0.7^{b}$ & $1.04^{\mathrm{c}}$ & $1.04^{\mathrm{a}}$ & $0.96^{\mathrm{ab}}$ & $4.00^{\mathrm{a}}$ & $6.68^{b}$ & $0.80^{\mathrm{b}}$ & $0.99^{\mathrm{c}}$ & $3.09^{b}$ & $6.60^{b}$ & $0.412^{\mathrm{a}}$ & $0.00^{\mathrm{c}}$ & $0.745^{\mathrm{a}}$ & $0.723^{\mathrm{a}}$ \\
\hline Persimmon. & $1.2^{\mathrm{a}}$ & $2.23^{\mathrm{b}}$ & $0.98^{\mathrm{ab}}$ & $1.05^{\mathrm{a}}$ & $3.99^{\mathrm{a}}$ & $9.48^{\mathrm{a}}$ & $1.20^{\mathrm{a}}$ & $2.34^{b}$ & $4.66^{\mathrm{ab}}$ & $22.2^{\mathrm{a}}$ & $0.374^{\mathrm{a}}$ & $2.10^{\mathrm{a}}$ & $0.734^{\mathrm{a}}$ & $0.649^{b}$ \\
\hline Carrots. & $1.5^{\mathrm{a}}$ & $1.74^{\mathrm{c}}$ & $0.94^{\mathrm{ab}}$ & $0.90^{b}$ & $3.99^{\mathrm{a}}$ & $6.86^{b}$ & $1.40^{\mathrm{a}}$ & $1.56^{\mathrm{c}}$ & $5.55^{\mathrm{a}}$ & $10.7^{\mathrm{b}}$ & $0.221^{b}$ & $0.00^{\mathrm{c}}$ & $0.772^{\mathrm{a}}$ & $0.741^{\mathrm{a}}$ \\
\hline Pumpkin. & $1.0^{\mathrm{ab}}$ & $0.99^{d}$ & $0.96^{\mathrm{ab}}$ & $1.01^{\mathrm{a}}$ & $3.20^{b}$ & $5.85^{c}$ & $1.00^{\mathrm{ab}}$ & $1.00^{\mathrm{c}}$ & $3.19^{b}$ & $5.80^{b}$ & $0.372^{\mathrm{a}}$ & $0.10^{d}$ & $\mathbf{0 . 7 8 3}^{\mathrm{a}}$ & $0.754^{\mathrm{a}}$ \\
\hline Wholly Prickly Pear. & $1.2^{\mathrm{a}}$ & $0.62^{d}$ & $0.93^{\text {ab }}$ & $0.97^{\mathrm{ab}}$ & $3.97^{\mathrm{a}}$ & $5.47^{\mathrm{c}}$ & $1.10^{\mathrm{ab}}$ & $0.60^{d}$ & $4.38^{\mathrm{ab}}$ & $\mathbf{3 . 3 0}^{\mathrm{b}}$ & $0.279^{b}$ & $0.00^{\mathrm{c}}$ & $\mathbf{0 . 7 8 8}^{\mathrm{a}}$ & $0.752^{\mathrm{a}}$ \\
\hline
\end{tabular}

*Means followed by different letters in the same column are significant differences by Duncan's multiple tests (p $\leq 0.05)$.

samples were the highest values, however pumpkin sample was slightly lower than the others. On the other wise, after storage period, also all samples compared to both of (control and blank samples) had increased their values doubled except both of pumpkin and wholly prickly pear were moderate increased. Gumminess; before storage period of [carrot and control sample which were the same value (1.20)] as well persimmon sample were the best. Wholly prickly pear and pumpkin, respectively, were moderate while strawberries as that of blank marshmallow sample were the lowest. On the other side, after storage period, there is an increase in the characteristic, with clear significant differences at $(p<0.05)$., between amount of doubled to slight as follows; the control sample, blank, and persimmon, were double increase, followed by strawberries and carrot were slightly increase, while there was no increase in pumpkin sample value, but there was a clear decreased in wholly prickly pear value. Chewiness; before storage period, carrot marshmallow sample which had represented the highest values and was the best, followed by persimmon and wholly prickly pear, respectively., compared to both of control and blank samples, while pumpkin and strawberries were low. However after storage period persimmon marshmallow sample was superior followed by control and carrot samples were the highest, while blank, strawberries, and pumpkin were moderate increased, but wholly prickly pear was decreased. Adhesiveness; here, before storage period, it could be observed that, the lowest values all of samples, this means that more good the product. Strawberries had a high value followed by persimmon and pumpkin samples compared to blank sample, while carrot and wholly prickly pear were as that of control sample and the best. After storage period, strawberries, carrot, and wholly prickly pear samples had represent value $(0.0)$ and the best which as that of blank (with golden syrup) sample. Pumpkin was low and close to control, that was good. Persimmon was the highest value, that means the worst. From these result, it could be concluded that, the effect of storage on the rheological properties for the marshmallow product, it was either increases the quality of the product's properties or reduce it, and furthermore packaging and storage are important issue.

The results in Table (4) had presented the data on the water activity $\left(a_{w}\right)$ of the marshmallow samples, since the water activity there were higher than (0.6) and lower than (0.9) whether it was before or after storage. At the same time, close correlation between the activity of water and the moisture can be seen from previous data in Table (1) Fatianov ( 2015). In general, it could be observed that, there are no significant differences at $(\mathrm{p} \leq 0.05)$, whether it was before or after storage, ( Hough et al., 2001). 
The rehydration times (per one hr.,) are given in Table (5). Reconstitution ratio of water absorbed by control (commercial marshmallow) sample increased in their values by increasing soaking time, while were supposed to decrease with increasing the time rehydration.
From the results in Table (6). It could be indicated that, it could be concluded that, a sensory evaluation was performed to determine the optimal raw material for marshmallow candies be made from natural fruits / vegetable juices. The organoleptic tests were used to test

Table (5): Reconstitution Ratio Samples for Marshmallow Free of Syrup Products.

\begin{tabular}{|c|c|c|c|c|c|c|}
\hline $\begin{array}{l}\text { Rehyd., Time (per } 1 \text { hr.). } \\
\text { Treatments. }\end{array}$ & $1 \mathrm{hr}$. & 2 hrs. & 3 hrs. & 4 hrs. & 5 hrs. & 6 hrs. \\
\hline$* *$ Control (Commercial) & $116.7^{b}$ & $133.3^{\mathrm{a}}$ & $133.3^{\mathrm{a}}$ & $133.3^{\mathrm{a}}$ & $133.3^{\mathrm{a}}$ & $133.3^{\mathrm{a}}$ \\
\hline Blank (with golden syrup). & $85.7^{\mathrm{a}}$ & $85.7^{\mathrm{a}}$ & $71.4^{b}$ & $71.4^{b}$ & $71.4^{\mathrm{b}}$ & $57.1^{\mathrm{c}}$ \\
\hline Strawberries & $66.7^{\mathrm{a}}$ & $66.6^{\mathrm{a}}$ & $50.0^{b}$ & $33.3^{c}$ & $16.7^{d}$ & $16.7^{d}$ \\
\hline Persimmon. & $85.7^{\mathrm{a}}$ & $71.4^{b}$ & $71.4^{b}$ & $57.1^{c}$ & $57.1^{\mathrm{c}}$ & $57.1^{\mathrm{c}}$ \\
\hline Carrots. & $100.0^{\mathrm{a}}$ & $88.9^{b}$ & $77.7^{\mathrm{c}}$ & $77.7^{\mathrm{c}}$ & $66.7^{d}$ & $66.7^{d}$ \\
\hline Pumpkin. & $100.0^{\mathrm{a}}$ & $88.7^{b}$ & $71.4^{\mathrm{c}}$ & $71.4^{\mathrm{c}}$ & $57.1^{d}$ & $57.1^{d}$ \\
\hline Wholly Prickly Pear. & $100.0^{\mathrm{a}}$ & $83.3^{b}$ & $66.7^{\mathrm{c}}$ & $66.7^{\mathrm{c}}$ & $50.0^{d}$ & $33.3^{\mathrm{e}}$ \\
\hline
\end{tabular}

*Means followed by different letters in the same column are significant differences at $p \leq 0.05$.

On the other hand, all of samples under study had taken to decrease in value's reconstitution ratio after (6 hrs.) of rehydration time including blank (with syrup) marshmallow sample compared to control. Meanwhile, after (6 hrs.) for rehydration time most of samples including blank sample had took rapid deterioration. Hence, after (6 hrs.) rehydration time of blank sample as well as all of samples had clearly significantly different at $\mathrm{p} \leq 0.05$. Results revealed that, reconstitution ratio values for carrot sample followed by pumpkin, and persimmon compared to blank were the best with significantly differences between them, but the least one was wholly prickly pear had the worst value's reconstitution ratio after (6 hrs.,) of rehydration time compared to both of control and blank samples, according to (Kirtil et al.,2017). for differences between preferences of the marshmallow samples. The analysis showed significant difference at $p \leq 0.05$., in the degree of liking between the control (commercial) sample and samples with wholly prickly pear, strawberries, and pumpkin that had the same score recorded. Consumers recognized the marshmallow sample with these strawberries, wholly prickly pear, and pumpkin as well blank (with golden syrup) as having a too typical taste, sharp flavor, and a so airy structure. Thus, the consumer preferred the classical marshmallow with golden syrup (blank), strawberries, and pumpkin as well wholly prickly pear enriched marshmallow compared control sample that were in agreement with Ungure et al., (2013).

Table (6) Sensory Evaluation of Different Suggestion Marshmallow (Free of Golden Syrup) Products.

\begin{tabular}{|c|c|c|c|c|c|c|c|}
\hline Samples. & $\begin{array}{c}\text { Appearance } \\
(10)\end{array}$ & $\begin{array}{c}\text { Color } \\
(10)\end{array}$ & $\begin{array}{c}\text { Flavor } \\
(10)\end{array}$ & $\begin{array}{c}\text { Texture } \\
\text { (10) }\end{array}$ & $\begin{array}{l}\text { Taste } \\
(10)\end{array}$ & $\begin{array}{c}\text { Overall Score } \\
(\mathbf{5 0 )}\end{array}$ & $\begin{array}{c}\text { Overall } \\
\text { Palatability }\end{array}$ \\
\hline$* *$ Control (Commercial). & $8.3^{b}$ & $8.9^{a b}$ & $8.3^{b}$ & $8.4^{b}$ & $8.0^{b}$ & $41.9^{b}$ & $\mathbf{G}$ \\
\hline Blank (with golden syrup). & $8.7^{\mathrm{ab}}$ & $9.4^{\mathrm{a}}$ & $8.2^{b}$ & $9.7^{\mathrm{a}}$ & $8.6^{\mathrm{ab}}$ & $44.6^{\mathrm{a}}$ & $\mathbf{V}$ \\
\hline Strawberries & $8.7^{\mathrm{ab}}$ & $8.3^{b}$ & $9.0^{\mathrm{a}}$ & $9,1^{\mathrm{a}}$ & $9.5^{\mathrm{a}}$ & $44.6^{\mathrm{a}}$ & V \\
\hline Persimmon. & $8.7^{\mathrm{ab}}$ & $8.1^{b}$ & $7.8^{b}$ & $8.2^{b}$ & $7.7^{b}$ & $40.5^{b}$ & $\mathbf{G}$ \\
\hline Carrots. & $8.7^{\mathrm{ab}}$ & $9.2^{\mathrm{a}}$ & $8.6^{\mathrm{ab}}$ & $8.7^{b}$ & $8.5^{b}$ & $43.7^{\mathrm{ab}}$ & $\mathbf{G}$ \\
\hline Pumpkin. & $9.3^{\mathrm{a}}$ & $8.7^{\mathrm{ab}}$ & $8.4^{\mathrm{ab}}$ & $9.6^{\mathrm{a}}$ & $8.9^{\mathrm{ab}}$ & $44.9^{\mathrm{a}}$ & $\mathbf{V}$ \\
\hline Wholly Prickly Pear. & $9.2^{\mathrm{a}}$ & $8.4^{\mathrm{b}}$ & $8.5^{\mathrm{ab}}$ & $9.5^{\mathrm{a}}$ & $9.0^{\mathrm{a}}$ & $44.6^{\mathrm{a}}$ & $\mathbf{V}$ \\
\hline
\end{tabular}

${ }^{*}$ Means followed by different letters in the same column are significant differences at $p \leq 0.05$. 


\section{Conclusion and recommendation}

Finally, it could be concluded through this study that it is available, technical and economic to manufacture different kinds of marshmallow from (fruits / vegetable) juices which had great palatability among the majority of different consumers all over the world. The developed marshmallow it's processed from natural local raw materials it is a high quality product that helps to solve the problem of iron, zinc, calcium and magnesium deficiency for children.

\section{REFERENCES}

Aromatic F. A., Elmhdwi M. F., Aromatic F., and Aromatic O. O. (2013). Estimation of antioxidant activities of fixed and volatile oils extracted from Aromatic aromatic (clove).Der Chemica Sinica, 4(3):120-125.

Association of Official Analytical ChemistsAOAC. (2019). Official Methods of Analysis, $21^{\text {st }}$ ed. Washington, D.C., AOAC. USA.

Bourne M. (1978) Texture profile analysis, Food Tech. 32: 62.

Daily-Intake,

FDA

(2020).

www.fda.gov/nutritioneducation

Interactive Nutrition Fact Label_Vitamins and Minerals Chart(1)_March, (2020). FDA.U.S. Food and Drug Administration.

Demirhan Y., Ulca P ., Senyuva H. Z. (2012). Detection of porcine DNA in gelatine and gelatine-containing processed food products. Halal/Kosher authentication. Meat Sci., 90 (3): 686-689.

Ergun R., Lietha R., Hartel R. W.(2010). Moisture and shelf life in sugar confections. Crit. Rev. Food Sci. Nutr., 50 (2):162-192.

Fatianov E.V.( 2015). Significance of water activity factor in the technology of animal products. Proceedings of XII International theoretical and practical conference "Food. Ecology. Quality". Saratov, n .p. (In Russian).

Goycoolea F. M., and Cárdenas A., (2003). Pectins from Opuntia spp.: A short review. J. Professional Asso. Cactus Development, 5: 17-29.

Hill M. J., (1997). Nutrition and human cancer. Ann. NY Acad. Sci., 833: 68-78.

Hough G., Pilar-Buera M. del Chirife J. and Moro O.( 2001). Sensory texture of commercial biscuits as a function of water activity. Journal of Text. Stud.32(1):5774.
Kirtil E., Aydogdu A. and Oztop M. H. (2017). Investigation of physical properties and moisture sorption behaviour of different marshmallow formulations. Act. Hort., 33 (1152): 243-248.

Kirtil E., Aydogdu A., Elik S. and Oztop M. H. (2015). Effect of sugar type and water content on the physical properties of marshmallows. J Food Process Technol. volume 6 , issue 8 ., http://dx.doi..org.

Kolmakova N. S. (2008). Poslednie issledovanija $\mathrm{V}$ oblasti bezopasnosti sinteticheskih krasitelej. Tendencii razvitija rynka. Pivo inapitki, (5) : 56-57.

Ungure E., Straumîte E., Muipniece-Brasava S., and Dukaïska L.,(2013). Consumer Attitude and Sensory Evaluation OF Marshmallow. Proc. Latvian Acad. Sci., Section B, Vol. 6, No. 4/5: 442-447.

Miean K. H. and Mohamed S. (2001).Flavonoid (myricetin, quercetin, kaempferol, luteolin, and apigenin) content of edible tropical plants. J. Agric. Food Chem., (49): 3106-3112.

Minifie B.W. (1989). Chocolate, cocoa, and confectionery: science and technology. New York: Van Nostrand Reinhold. p 885.

Nepovinnykha N. V., Klyukinaa O. N., Kodatskiya Y. A., Ptichkinaa N. M. and Yeganehzad S., (2018). Study of the stability of foam and viscoelastic properties of marshmallow without gelatin. Foods and Raw Materials., 6 (1): 9

Periche Santamaría A., Castelló Gómez M.L., Heredia Gutiérrez A.B., Escriche Roberto MI. (2016). Stevia Rebaudiana, Oligofructose and Isomaltulose as sugar replacers in marshmallows stability and antioxidant properties. Journal of Food Processing and Preservation. 40:724-732.

Periche Santamaría A., Heredia Gutiérrez A.B., Escriche Roberto M.I., Andrés Grau A.M., Castelló Gómez ML. (2015). Potential use of isomaltulose to produce healthier marshmallows. Food Science and Technology. 62(1):605-612.

Pietta P.G.(2000). Flavonoids as Antioxidants. J. Nat. Prod., 63: 1035-1042.

Ranganna S.C. (1977). Manual of analysis of Fruit and Vegetable Products, Tata. McGraw- Hill Publishing Company Limited. New Delhi, India. 
Rockland L. B. and Nishi S. K. (1980). Fundamentals of Water Activity. Food Tech., 34: 42-59.

SAS (1997). Statistical Analysis System. User's Guide, Statistics, SAS Institute Inc, Gary, Nc., USA.

Sendecor G.W. and Cochran W.C. (1997). Statistical Methods; $7^{\text {th }}$ Ed. Oxford and j; B.H. Publishing Co., Oxford University Press : 504.

Sepúlveda E., Sáenz C., Aliaga E., and Aceituno C. (2007). Extraction and characterization of mucilage in Opuntia spp., Journal of Arid Environments 68: 534- 545.

Sucharzewska D., Stochmal A., Oleszek W. (2003). The effect of Yucca schidigera extract on the physical structure and on the oxidative stability of sugar-candy foam products. Lebensmit. Wiss. Tech., 36 (3), 347-351.

Szczesniak A., Brandt $M$. and Freidman H.(1963). Development of standard rating scales for mechanical parameters and correlation between the objective and sensory texture measurements, Food. Tech., 22:50.

Von-Loesecke K.W. (1955). Drying and dehydration of food, Reinhold publishing corporation New York USA.,Chapman and Hall Ltd., London., UK.

Watts B. M.,Ylimaki G.L., Jeffery L.E. and EliasL.G.(1989). Basic Sensory Methods for Food Evaluation, International Development Research CInternational Development Research Centre, PO Box 8500, Ottawa, Ontario, Canada KlG 3H9 60-63.

Daily-Intake, FDA www.fda.gov/nutritioneducation Interactive Nutrition Fact Label_Vitamins and Minerals Chart(1)_March, (2020). FDA.U.S. Food and Drug Administration.

Zharinov A.I., Mitaseva L.F., Spassky K.G. (2009). Experimental determination of water activity value in water gels of food hydrocolloids. Meat Industry, $12: 27-29$. (InRussian). 


\title{
إنتاج حلوى المارشيمللو الخالي من شراب الجلوكوز باستخدام عصائر بعض الفواكه والخضروات. نسرين محمد السعيد على
}

معهد بحوث تكنولوجيا الاغذية ـ مركز البحوث الزراعية ـ الجيزة - مصر.

\begin{abstract}
ملخص
المارشيمللو هو نوع خاص من الحلوى السكرية اسفنجية القو ام عند المضن، و التى تحضر بشكل أساسى من مكونين
\end{abstract}

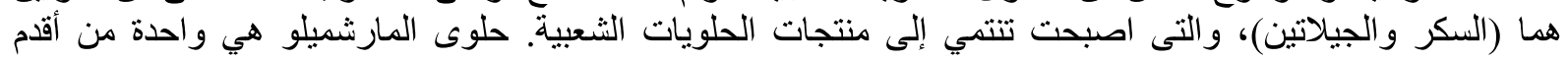

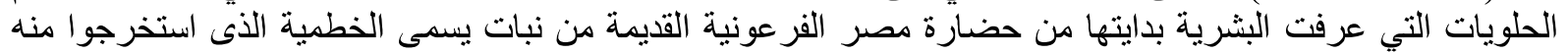

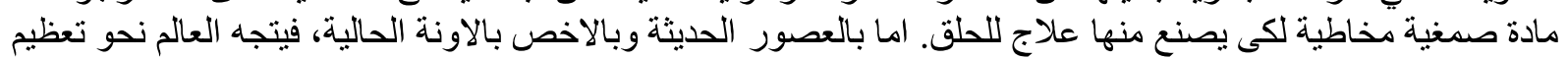

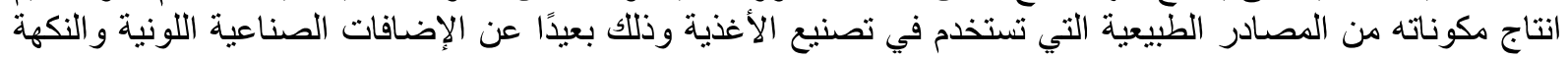

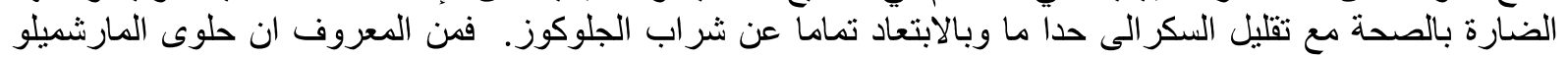

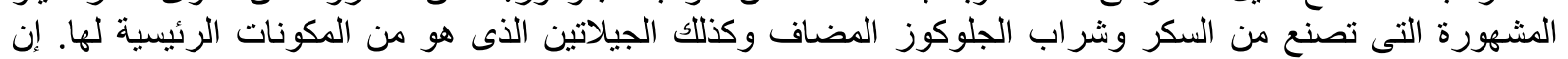

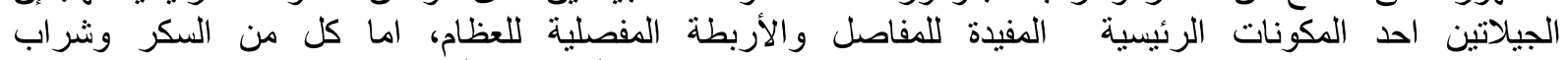

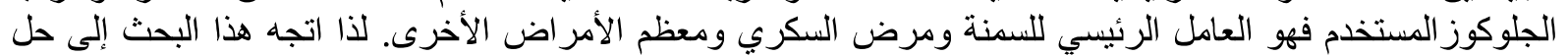

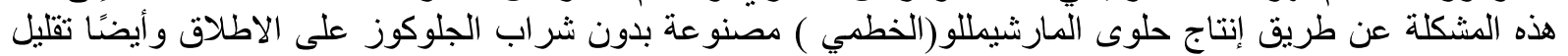

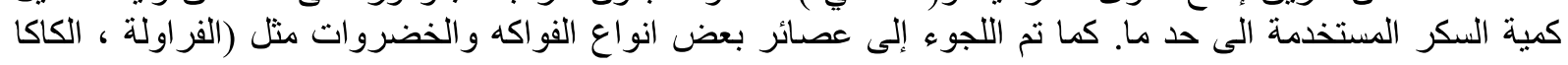

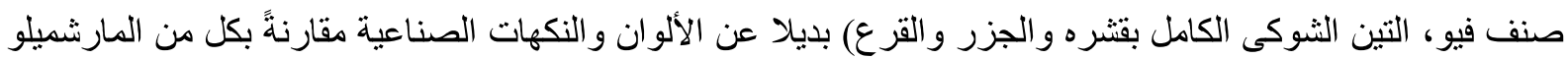

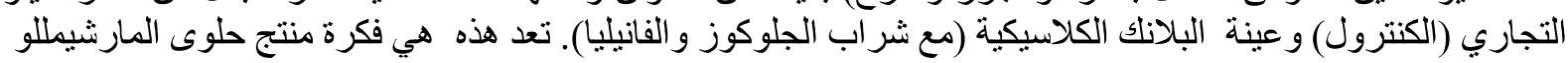

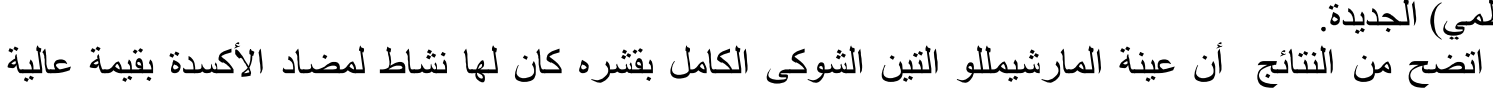

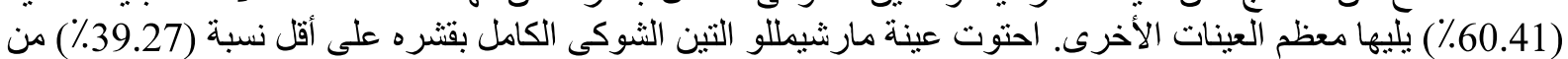

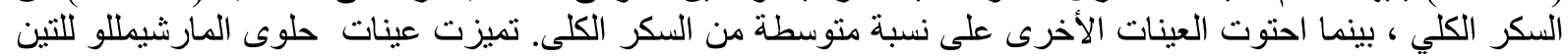

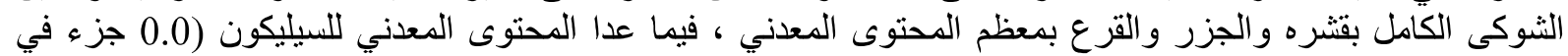

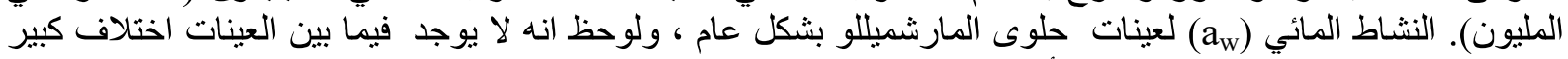

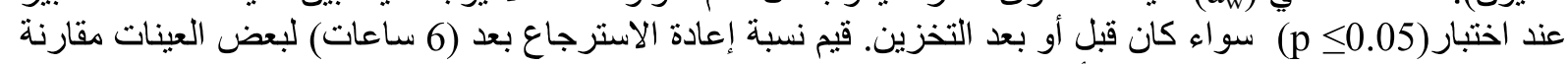

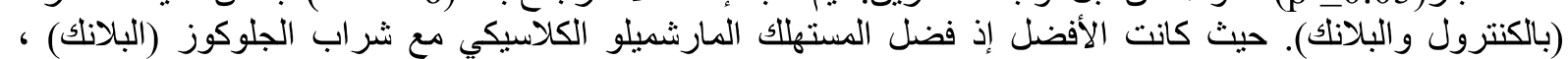

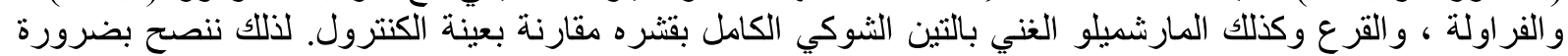

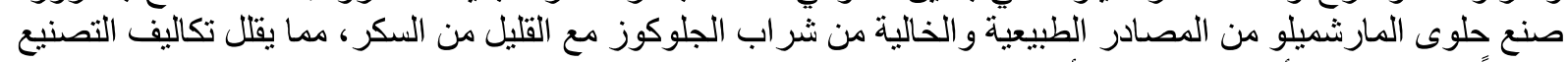

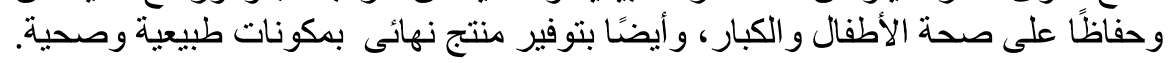

